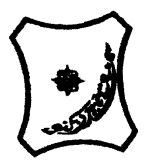

Bayero Journal of Pure and Applied Sciences, 10(1): 170 - 177

Received: November, 2016

Accepted: April, 2017

ISSN $2006-6996$

\title{
EFFECTS OF LIQUID NITROGEN FERTILIZER AND BENZYL AMINO PURINE (BAP) ON MINERAL ELEMENTS AND LIPID CONTENT IN RELATION TO SENESCENCE OF TWO COWPEA VARIETIES
}

\author{
*Mohammad, M. ${ }^{1}$ and Mukhtar, F. B. ${ }^{2}$ \\ 1. Department of Biological Science, Federal University Dutse. \\ 2. Department of Plant Biology, Bayero University Kano, Nigeria. \\ * Correspondence Author: maryammohammad35@yahoo.com.08023778967.
}

\begin{abstract}
The effects of combined treatment of liquid nitrogen fertilizer and benzyl amino purine (BAP)was studied on mineral elements (Magnesium, Phosphorus, Potassium, Calcium, sodium, iron and Manganese) and lipid content in relation to senescence. The experimental site for this study was situated at the botanical garden of the Biological Science Department of the University of Lagos, Nigeria. The cowpea varieties used for this study were, Kanannado, a local cowpea variety and IT 89KD - 288 an improved variety which are photosensitive, there were four treatments namely nitrogen fertilizer, BAP, combined treatment of liquid nitrogen fertilizer and BAP and then the control, there were 15 replications for each treatment. The procedure involved foliar spray of the plants with liquid nitrogen fertilizer (100mI in 15 liters of water), BAP at 200ppm concentration, combined treatment of liquid nitrogen fertilizer with BAP at 3:1 ratio while the control plants were foliarly sprayed with distilled water, the spray was done at 3, 6, and 9 weeks after planting. The rainy season trial was carried out on the $9^{\text {th }}$ of August 2012 , while the dry season trial was carried out on $20^{\text {th }}$ January 2013. IT89KD-288 had the highest content of calcium and potassium while Kanannado had the highest content of magnesium, phosphorus, sodium, iron and manganese. While comparison between the treatment showed that the treatment with the highest mineral elements contents such as Phosphorus, Potassium, Calcium, Sodium and Iron in the varieties was the combined treatment of liquid nitrogen fertilizer and BAP (150\%N+200ppm BAP), while 200ppmBAP had the highest content of Magnesium and Manganese. $150 \% \mathrm{~N}$ treatment had the highest content of calcium; the control plants had the least content of all the mineral elements. Comparison between the two seasons, the result had shown that there were more mineral elements in the rainy season than in the dry season. With regards to lipid content comparison between the treatments has shown that the variety IT89KD-288 had the highest lipid content at 6 weeks only but at 9 and12 weeks Kanannado had the highest content. Between the treatments, $150 \% N+B A P$ had the highest content followed by 150\%N at 6 weeks but at 9 and 12 weeks there was more lipid with 200ppm BAP, between the two seasons, there was more lipid in the rainy season than dry season. The significant findings of this study is that the combined treatment of liquid nitrogen fertilizer and BAP (150\%N+200ppm BAP) improved the mineral element and lipid content and delay senescence in the two cowpea varieties. Therefore could be recommended for usage to farmers.
\end{abstract}

Keywords: Cowpea, Benzyl Amino Purine, Lipid, senescence, Fertilizer.

\section{INTRODUCTION}

Based on the amount needed, mineral elements are usually classified into two groups: macro elements and microelements. Macro elements consist of elements in large supply, while microelements are usually only needed in trace amount. Lipids are basically structural and functional molecules of plant cells and tissues. They are known to affect certain membrane properties like permeability, fluidity and transport. In particular, lipids are sensitive to any change in physiological state as well as biotic and abiotic environments (Brown et al., 1987; Droillard et al., 1989; Duxbury et al., 1991; Paliyath and Droillard, 1992).
Senescence means aging that ultimately leads to death. Plant aging and environmental stresses may induce the process of senescence. In plants senescence is a complex and highly regulated process that occurs as part of plant development. It is a preplanned process, which can be seen in annuals such as rain crops that turn from green to golden as the grain ripens - before harvest. These changes visible to the naked eye are accompanied with internal biochemical events; in which nutrients are being transferred from the leaves to other organs in the plant to be used in its development (Green and Jones, 1982). 
Bajopas Volume 10 Number 1 June, 2017

Cowpea (Vigna unguiculata(L.)Walp.), a protein-rich legume crop, is immensely important in many parts of the world, particularly in drought-prone regions of Africa and Asia, where it plays a central role in the diet and economy of hundreds of millions of people (Fery and Singh, 1997; Singh et al., 2003).

Cowpea is grown primarily for its edible seeds but young leaves are also harvested and consumed as leafy vegetables often prepared as salad for direct consumption or eaten as relish along with other foods (Nielsen et al., 1997; Noubissié et al., 2011). According to Nielsen et al. (1997), Ahenkora et al., (1998), Maposse and Nhampalele (2009), it is among the top three or four leafy vegetables used in Africa and represents cheaper plant-protein source particularly in areas where food security and malnutrition are a major challenge. Fresh and dried cowpea leaves from home gardens and field production are sold in many African markets by resource-poor families (Sebetha et al., 2010).

In cowpea senescence causes substantial reduction in total grain yield because most cowpea plants die after producing the first flush of pods. The reduction in yield is most drastic in the local varieties. Delaying leaf senescence will most probably extend the reproductive period and increase the photosynthetic efficiency of the crop resulting in increased grain yield. The aim of the experiment is to evaluate the single and combined effect of nitrogen fertilizer and BAP on mineral element and lipid content in relation to senescence.

\section{MATERIALS AND METHOD}

This study was conducted in the screen house of the Biological Science Department at the University of Lagos located in the south western part of Nigeria. Lagos is situated at latitude $6^{\circ} 27^{\prime} 11^{\prime \prime} \mathrm{N}$, longitude $3^{\circ} 23^{\prime} 45^{\prime \prime} \mathrm{E}$ and altitude $0-41 \mathrm{~m}(0-135 \mathrm{ft})$. In the koppen climate classification Lagos has a tropical wet and dry climate that borders on a tropical monsoon climate. Lagos experiences two rainy seasons, with the heaviest rains falling from April to July and a weaker rainy season in October and November. There is a brief relatively dry spell in August and September and a longer dry season from December to March. Monthly rainfall between May and July averages over $400 \mathrm{~mm}$ (16 in), while in August and September it is down to $200 \mathrm{~mm}$ (7.9 in) and in December as low as $25 \mathrm{~mm}$ (0.98 in). The main dry season is accompanied by harmattan winds from the Sahara Desert, which between December and early February can be quite strong. The highest maximum temperature ever recorded in Lagos was $37.3^{\circ} \mathrm{C}$ $\left(99.1^{\circ} \mathrm{F}\right)$ and the minimum $13.9^{\circ} \mathrm{C}\left(57.0^{\circ} \mathrm{F}\right)$. (world weather information service Lagos, 2012)

\section{Planting}

Plastic pots of $250 \mathrm{~mm}$ diameter in height were used in this study. They were filled with fresh sandy loam top soil and watered well for two days before planting. There were fifteen replications per treatment. The treatments were replicated using completely randomize design. The treatments used include Benzyl Amino Purine (BAP) and liquid Nitrogen fertilizer (Boost Extra). There were also combined treatments of BAP and liquid Nitrogen fertilizer. The procedure involves foliar spray with the treatments at $3: 1$ ratio of liquid fertilizer and hormone respectively.
The first planting was done on the $9^{\text {th }}$ of August, 2012 for the rainy season trial and the second planting was done on the $20^{\text {th }}$ of January, 2013 for the dry season trial. Seeds were directly sown on the prepared pots (after surface treatment with fungicide Apron plus) at 2 seeds per pot. Later they were labeled and placed in completely randomized design (CRD) and labeled appropriately using white and green plastic tags according to the plant treatment applied.

\section{DATA COLLECTION}

Destructive sampling of the treated and control plants were carried out. Three replicates were collected at each sampling date and averages recorded. Sampling for determination of mineral elements content was carried out at 6, 9 and 12 weeks after planting. One gram $(1.0 \mathrm{~g})$ of the leaves was ashed and cooled, the ash was dissolved in $10 \mathrm{~cm}^{3}$ of $10 \%$ nitric acid and was made up to the mark in a $100 \mathrm{~cm}^{3}$ volumetric flask with water. Calcium, carbon, magnesium, manganese, and iron were determined at their respective wavelengths $(660 \mathrm{~nm})$ using Alpha - 4 model of Atomic Absorption Spectrophotometer (AAS). Sodium and potassium were determined using flame photometer model JENWAY - PF7 at 660nm wavelength. Lipids analysis was determined using the soxhlet extraction method as reported by Usoro et al (1982). While for senescence, number of days to onset of senescence were counted and recorded for each plant. Other parameters recorded were number of days to $50 \%$ senescence, days to $90 \%$ senescence and days to complete death of plant. From the data obtained the duration of senescence in the different treated and control plants was estimated in order to determine their effects on senescence in the cowpea varieties.

\section{Statistical Analysis}

The data collected was subjected to one-way Analysis of Variance (ANOVA) using GENSTAT software and means with significant differences were separated using least significance difference test at $P \leq 0.05$.

\section{RESULTS AND DISCUSSION}

\section{Mineral Elements Content in the Different} Varieties, Treatments and Seasons

Table 1 showed that there was more calcium (201.20), potassium (164.94), and phosphorus (58.04) in the improved variety of IT89Kd-288 then the local variety kanannado. In a similar work, results were obtained with the improved cowpeas where they were found to contain relatively higher amount of calcium, phosphorus, and potassium content (Olaleke et al; 2006). On the other hand, it was also found by Asante et al; 2006 that local cowpea varieties had higher mineral magnesium and manganese and iron concentrations compared to the improved varieties. Comparison of the treatments showed that the plants with the highest mineral elements contents such as Phosphorus, Potassium, Calcium, Sodium and Iron in the varieties were those treated with the combined treatment of $150 \% \mathrm{~N}+200 \mathrm{ppm}$ BAP at 6,9 and 12 weeks, while those plants treated with 200ppmBAP had the highest content of Magnesium and Manganese at 6, 9 and 12 weeks with significant difference. Plants treated with $150 \% \mathrm{~N}$ treatment had the highest content of calcium with significant difference; the control plants had the least content of all the mineral elements (Table 2). 
Bajopas Volume 10 Number 1 June, 2017

In this study all the elements were remarkably affected by Nitrogen fertilizer application. Gomide et al., 1989 also found that application of nitrogen fertilizer to grasses increased their mineral content, and also reported that application of $\mathrm{K}$ fertilizers resulted in increased $\mathrm{Mg}$ concentration in the herbage while the level of $K$ subsequently increased.

Comparison between the two seasons, the result had shown that there were more mineral elements in the rainy season than in the dry season with regards to magnesium, manganese, calcium, iron and potassium at 6,9 and 12 weeks and the difference between them was significant, while sodium was more in the dry season, but phosphorus was more in the dry season at 6 weeks but the difference was not significant, at 9 and 12 weeks there was more of it in the rainy season. (Table3). That there was more magnesium, during the rainy season than the dry season, as could be attributed to the fact that in the dry season competing cations in the soil such as $\mathrm{Ca}^{2+}$, $\mathrm{H}^{+}, \mathrm{NH}^{+}, \mathrm{Al}^{+}$and $\mathrm{Na}^{+}$prevent Magnesium intake by the plant.(Jones 1983). The greater calcium level in the wet season than during the water stress period (dry season) could be that the plant used more calcium in the dry season to deal with all injuries which happened as a result of the water stress. This is in line with Palta, (2000), who states that Calcium is considered to play a role in mediating stress response during injury, recovery from injury and acclimation to stress.

The decrease in Potassium level in the dry season could be due to the excessive use of $\mathrm{K}$ by the plant in the dry season to carry out its physiological processes. This agrees with Ejaz et al. (2011), who said that Potassium plays an important role in the survival of plants under stress conditions. The decrease in Phosphorus level in the dry season could be attributed to the dryness of the soil because Phosphorus in the soil is not made available to the root of the plant for uptake. The roots cannot absorb the Phosphorus in the solid form; they can only absorb it in the liquid form. This renders plants incapable to accumulate Phosphorus in the dry season. This agrees with the findings of Havlin et al. (2007), that, Phosphorus is found less in quantity in dry soils.

\section{Lipid Content in the Different Varieties, Treatments and Seasons}

There was a decrease in the lipid content of the cowpea varieties as the number of weeks after sowing increased from 6- 12 weeks. The difference was observed to be significant at $P \leq 0.05$ (Table 4). Comparison of the two cowpea varieties has shown that the IT89KD-288 leaves had more lipid content than the leaves of Kanannado at 6 weeks only, but at 9 and 12 weeks there was more lipid in the leaves of kanannado than in IT89KD-288 and the difference between them was significant interms of the liquid content. This was because of the early commencement of senescence in IT89KD-288.

All the treatments stimulated significantly greater lipid content compared with the control. Comparison of the treatment has shown that the combine treatment of Nitrogen fertilizer and BAP $(150 \% \mathrm{~N}+200 \mathrm{ppm}$ BAP) had the highest lipid followed by Nitrogen fertilizer treatment at 6 weeks but at 9 and 12 weeks there was more lipid in the leaves of cowpea treated with 200ppm BAP than in the leaves of cowpea treated with $150 \% \mathrm{~N}$. The difference between the treatments was significant (Table 4). Increased concentration of the lipid as a result of fertilizer application was earlier on observed by many researchers, Myers (1998), Amujoyegbe et al. (2001), Springer et al. (2005) and Tolera et al.(2006). Similar observation was also reported by Ricardo et al;(1987) in their work with four selections of three amaranth species in which they were fertilized with levels of $0,30,60$ and $90 \mathrm{~kg} / \mathrm{ha}$ of a 12-24-12 fertilizer formulation, in which the application of fertilizer increased the lipid content of all selections. There was a general increase in the concentration of lipids in the leaves of the plants studied with increase in the level of fertilizer treatment.

The lipid decreased as the number of days increased in all the varieties and in all the treatments which may be suggestive of substantial changes in ultrastructure, fluidity and permeability of the membrane. An earlier study revealed a greater decrease in lipid content in salt-stressed jojoba leaves (Ben-Rais et al., 1993). A report on Duboisia with reference to aging and senescence also revealed a significant decrease in lipid content (Mishra et al., 1998).

The results showed that there was a significant decline in the lipid content in both the rainy and dry seasons from 6 to 12 weeks after sowing, Between the two seasons that is rainy and dry season there was no significant difference between them in the lipid content at week 6 and week 9 but there was significant difference at 12 weeks interms of the lipid content, in which there was more of lipid in the rainy season than in the dry season (Table 4).

\section{Senescence in the Different Varieties,}

\section{Treatments and Seasons}

Table 5 showed the result of onset, progression and duration of senescence in the two cowpea varieties, In the variety Kanannado, there was a general delay in the number of days taken to the onset of senescence ( 72 days), days to $50 \%$ senescence (91 days), days to $90 \%$ senescence (102 days) and days to total death of the plant (42 days) ,when compared with IT89KD - 288 which took 64, 81, 93, 102 and38 days for onset of senescence, days to $50 \%$ senescence, days to $90 \%$ senescence and days to total death of the plant respectively (Table 5). This shows that mobilization of nutrients and other molecules (indicating senescence) from source to sink were faster in the leaves of IT89KD-288 than in the leaves of Kanannado. It is reported by Castillo and Leon, 2008 that during leaf senescence, macromolecule breakdown occurs and nutrients are translocated to support growth of new vegetative tissues, seeds, or other storage organs. Lim et al., 2007 reported that during leaf senescence, the catabolism of macromolecules such as proteins, carbohydrates, lipids, and nucleic acids becomes predominant in leaves, while anabolic activities are strongly decreased, with some even lost. But leaf senescence is not just a passive degradation process, since senescence is also a way to remobilize nutrients from old and photosynthetically less efficient leaves to new vegetative tissues, developing seeds, or storage organs ( Lim et al., 2007). 
Comparison between the treatments and the control showed that Nitrogen fertilizer hastened senescence, while BAP treatment applied as a single treatment or in a combination with $\mathrm{N}$ fertilizer delayed senescence. The difference was significant $(P \leq 0.05)$ (Table 5). Nitrogen Fertilizer is not known to delay senescence. Several studies reported that $\mathrm{N}$ fertilizer is known to improve soil productivity and fertility which improved yield and quality of crops (Whalen, 2000; Maerere and Ishimine, 2001; Vanek, 2003). Soil treated with N fertilizer was found to be loose. This probably provided adequate aeration in the soil and improved microbial activities (Xio and Li, 2006). On the other hand turmeric plant when treated with Nitrogen fertilizer remained green longer and resulted in a higher vegetative growth and yield (Mazid, 1993; and Seobi, 2005 and Anes and Johnson, 1980). Several workers such as Nooden et al. (1979), Richmond and Lang (1994), reported that BAP and gibberellins retard senescence while Abcissic acid and ethylene tend to act as accelerators. Leaf senescence can be retarded locally by the application of BAP (Smith and Watson, 1988). Physiological studies suggest that BAP can regulate leaf senescence and that the internal BAP level drops with the progression of leaf senescence (Smith and Watson, 1988).

Effect of the two planting seasons (rainy and dry) on senescence is also presented in Table 5 . Onset of senescence, days to $50 \%$ and $90 \%$ senescence and total death of the plants were earlier in the dry season planting when compared with the rainy season planting with significant difference $(P \leq 0.05)$. In the rainy season, senescence commenced by 69 days and total death of the plants occurred by 117 days after planting, whereas onset of senescence in the dry season was recorded at 67 days and total death at 102 days after planting (Table 5 ).

\section{CONCLUSION}

There was significant difference between the two varieties on mineral elements content, IT89KD-288 had the highest content of Calcium and potassium while Kanannado had the highest content of Magnesium, phosphorus, sodium, Iron and manganese. However, there was significant difference between the treatments, the treatment with the highest mineral elements contents such as Phosphorus, Potassium, Calcium, Sodium and Iron in the varieties was the combined treatment $150 \% \mathrm{~N}+200 \mathrm{ppm}$ BAP while 200ppmBAP had the highest content of Magnesium and Manganese. $150 \% \mathrm{~N}$ treatment had the highest content of calcium, the control plants had the least content of all the mineral elements. With regards to the two seasons there were more mineral elements in the rainy season than in the dry season. With regards to lipid, there was more lipid in the variety Kanannado than the variety IT89KD-288. Increased in lipid content was observed in all the plants given fertilizer and hormonal treatments. The highest lipid content was in the plants treated with combined $150 \% \mathrm{~N}+200 \mathrm{ppm}$ BAP followed by the single $150 \% \mathrm{~N}$ treatment. This shows that increase in the concentration of lipid in the leaves of the plants by the fertilizer might be as a result of increased nutrients due to fertilizer application, which consequently led to increased absorption of nutrients by the plants. In conclusion, the variety kanannado that had the highest content of mineral elements and lipid content senescence was delayed; likewise combined liquid nitrogen fertilizer and BAP regulated the onset of senescence due to the highest content of mineral elements and lipid in them. Therefore, the more mineral elements and lipid contents in plant the more senescence is delayed, and the more the yield of the plant. $150 \% \mathrm{~N}+200 \mathrm{ppm}$ BAP improved the mineral element and lipid content and delay senescence in the two cowpea varieties. Therefore could be recommended for usage to farmers. 
Bajopas Volume 10 Number 1 June, 2017

Table 1: Mean mineral elements $(\mathrm{mg} / 100 \mathrm{~g})$ content of the two cowpea varieties.

\begin{tabular}{|c|c|c|c|c|c|c|c|c|c|c|c|c|c|c|c|}
\hline & \multicolumn{5}{|l|}{ Mg } & \multicolumn{5}{|l|}{$\mathbf{P}$} & \multicolumn{5}{|l|}{$\mathbf{K}$} \\
\hline Variety & 6 weeks & 9 weeks & 12 weeks & Mean & LSD & 6 weeks & 9 weeks & 12 weeks & Mean & LSD & 6 weeks & 9 weeks & 12 weeks & Mean & LSD \\
\hline IT89KD288 & 122.55 & 117.66 & 106.88 & 115.69 & 3.647 & 62.96 & 57.18 & 54.00 & 58.04 & 2.109 & 173.24 & 165.25 & 156.33 & 164.94 & 3.856 \\
\hline Kanannado & 131.31 & 129.36 & 124.42 & 128.36 & 2.747 & 62.05 & 60.10 & 59.72 & 60.62 & 1.876 & 170.84 & 164.10 & 157.20 & 164.05 & 3.452 \\
\hline Mean & 126.93 & 123.51 & 115.65 & & & 62.51 & 58.64 & 56.86 & & & 172.04 & 164.67 & 156.77 & & \\
\hline LSD (0.05\%) & 3.208 & 7.694 & 1.767 & & & NS & 0.661 & 4.759 & & & NS & NS & NS & & \\
\hline & $\mathrm{Ca}$ & & & & & $\mathrm{Na}$ & & & & & $\mathbf{F e}$ & & & & \\
\hline Variety & 6 weeks & 9 weeks & 12 weeks & Mean & LSD & 6weeks & 9weeks & 12 weeks & Mean & LSD & 6weeks & 9weeks & 12 weeks & Mean & LSD \\
\hline IT89KD-288 & 190.53 & 199.03 & 214.05 & 201.20 & 4.296 & 84.98 & 80.76 & 77.63 & 81.13 & 3.950 & 4.013 & 3.609 & 3.201 & 3.607 & 0.2920 \\
\hline Kanannado & 182.05 & 188.08 & 196.61 & 188.91 & 4.370 & 80.35 & 79.60 & 75.65 & 78.53 & 2.860 & 3.896 & 3.679 & 3.521 & 3.698 & 0.2711 \\
\hline Mean & 186.29 & 193.56 & 205.33 & & & 82.67 & 80.18 & 76.60 & & & 3.954 & 3.644 & 3.361 & & \\
\hline LSD $(0.05 \%)$ & 3.24 & 12.10 & 6.28 & & & 3.389 & NS & NS & & & NS & NS & 0.259 & & \\
\hline & Mn & & & & & & & & & & & & & & \\
\hline Variety & 6 weeks & 9 weeks & 12 weeks & Mean & LSD & & & & & & & & & & \\
\hline IT89KD-288 & 3.438 & 3.011 & 2.888 & 3.112 & 0.198 & & & & & & & & & & \\
\hline Kanannado & 3.943 & 3.788 & 3.225 & 3.652 & 0.266 & & & & & & & & & & \\
\hline Mean & 3.690 & 3.399 & 3.056 & & & & & & & & & & & & \\
\hline $\operatorname{LSD}(0.05 \%)$ & 0.282 & 0.756 & 0.807 & & & & & & & & & & & & \\
\hline
\end{tabular}

Key: $\mathrm{Mg}$ = Magnesium, $\mathrm{P}=$ Phosphorous, $\mathrm{K}=$ Potassium, $\mathrm{Ca}=$ Calcium, $\mathrm{Na}=$ Sodium, $\mathrm{Fe}=$ Iron, $\mathrm{Mn}=$ Manganese

Table 2: Mean mineral elements $(\mathrm{mg} / 100 \mathrm{~g})$ content as affected by various treatments at different weeks

\begin{tabular}{|c|c|c|c|c|c|c|c|c|c|c|c|c|c|c|c|}
\hline & Mg & & & & & $\mathbf{P}$ & & & & & $\mathbf{K}$ & & & & \\
\hline Treatments & $\begin{array}{l}6 \\
\text { weeks }\end{array}$ & $\begin{array}{l}9 \\
\text { weeks }\end{array}$ & $\begin{array}{l}12 \\
\text { weeks }\end{array}$ & Mean & $\operatorname{LSD}(0.05 \%)$ & $\begin{array}{l}6 \\
\text { weeks }\end{array}$ & $\begin{array}{l}9 \\
\text { weeks }\end{array}$ & $\begin{array}{l}12 \\
\text { weeks }\end{array}$ & Mean & LSD & $\begin{array}{l}6 \\
\text { weeks }\end{array}$ & $\begin{array}{l}9 \\
\text { weeks }\end{array}$ & $\begin{array}{l}12 \\
\text { weeks }\end{array}$ & Mean & LSD \\
\hline $15 \% \mathrm{~N}$ & 127.6 & 121.1 & 109.4 & 119.7 & 5.07 & 68.16 & 60.53 & 53.92 & 60.87 & 2.218 & 175.55 & 164.45 & 155.86 & 165.29 & 3.125 \\
\hline 200ppmBP & 136.5 & 133.6 & 129.9 & 134.6 & 3.369 & 63.54 & 61.11 & 59.66 & 61.44 & 1.794 & 171.54 & 170.73 & 168.59 & 170.62 & NS \\
\hline $15 \% \mathrm{~N}+200 \mathrm{ppmBAP}$ & 138.6 & 127.8 & 120.7 & 127.7 & 4.542 & 66.44 & 64.70 & 62.44 & 64.53 & 2.429 & 182.65 & 176.04 & 164.34 & 174.35 & 3.332 \\
\hline Control & 108.61 & 108.15 & 103.10 & 106.62 & 4.992 & 51.89 & 48.3 & 43.42 & 47.84 & 2.310 & 158.42 & 146.47 & 138.27 & 147.72 & 7.90 \\
\hline Mean & 126.93 & 123.51 & 115.65 & & & 62.51 & 58.64 & 54.86 & & & 172.04 & 164.67 & 156.77 & & \\
\hline LSD $(0.05 \%)$ & 4.910 & 4.590 & 5.218 & & & 1.403 & 2.542 & 2.632 & & & 3.49 & 2.564 & 3.628 & & \\
\hline & $\mathrm{Ca}$ & & & & & $\mathrm{Na}$ & & & & & $\mathbf{F e}$ & & & & \\
\hline Treatments & $\begin{array}{l}6 \\
\text { weeks }\end{array}$ & $\begin{array}{l}9 \\
\text { weeks }\end{array}$ & 12 weeks & Mean & $\operatorname{LSD}(0.05 \%)$ & 6weeks & 9weeks & 12 weeks & Mean & LSD & $\begin{array}{l}6 \\
\text { weeks }\end{array}$ & $\begin{array}{l}9 \\
\text { weeks }\end{array}$ & 12 weeks & Mean & LSD \\
\hline $15 \% \mathrm{~N}$ & 195.11 & 201.37 & 213.16 & 203.21 & 6.41 & 82.79 & 81.77 & 76.94 & 80.50 & 4.707 & 4.197 & 3.640 & 3.322 & 3.720 & 0.309 \\
\hline 200ppmBP & 188.00 & 191.93 & 205.41 & 195.11 & 6.76 & 85.48 & 81.02 & 79.47 & 81.99 & NS & 4.121 & 4.040 & 3.946 & 4.036 & 0.325 \\
\hline $15 \% \mathrm{~N}+200 \mathrm{ppmBAP}$ & 199.01 & 205.22 & 215.79 & 206.67 & 5.69 & 89.30 & 89.42 & 85.47 & 88.06 & 3.441 & 4.374 & 4.319 & 3.722 & 4.138 & 0.381 \\
\hline Control & 163.04 & 175.72 & 186.95 & 175.24 & 7.85 & 73.10 & 70.08 & 63.14 & 68.77 & 4.595 & 3.206 & 2.672 & 2.421 & 2.766 & 0.357 \\
\hline Mean & 186.29 & 193.56 & 205.33 & & & 82.67 & 80.57 & 76.25 & & & 3.974 & 3.667 & 3.352 & & \\
\hline $\operatorname{LSD}(0.05 \%)$ & 5.12 & 5.73 & 7.79 & & & 3.050 & 6.39 & 1.55 & & & & & & & \\
\hline & Mn & & & & & & & & & & & & & & \\
\hline Treatments & $\begin{array}{l}6 \\
\text { weeks }\end{array}$ & $\begin{array}{l}9 \\
\text { weeks }\end{array}$ & 12weeks & Mean & $\operatorname{LSD}(0.05 \%)$ & & & & & & & & & & \\
\hline $15 \% \mathrm{~N}$ & 3.785 & 3.486 & 2.859 & 3.377 & 0.247 & & & & & & & & & & \\
\hline 200ppmBP & 4.012 & 3.921 & 3.656 & 3.863 & 0.344 & & & & & & & & & & \\
\hline $15 \% \mathrm{~N}+200 \mathrm{ppmBAP}$ & 3.981 & 3.620 & 3.508 & 3.703 & 0.330 & & & & & & & & & & \\
\hline Control & 3.073 & 2.777 & 2.202 & 2.684 & 0.301 & & & & & & & & & & \\
\hline Mean & 3.712 & 3.451 & 3.056 & & & & & & & & & & & & \\
\hline LSD (0.05\%) & 0.204 & 0.317 & 0.276 & & & & & & & & & & & & \\
\hline
\end{tabular}

Key: $\mathrm{Mg}=$ Magnesium, $\mathrm{P}=$ Phosphorous, $\mathrm{K}=$ Potassium, $\mathrm{Ca}=$ Calcium, $\mathrm{Na}=$ Sodium, $\mathrm{Fe}=$ Iron, $\mathrm{Mn}=$ Manganese 
Bajopas Volume 10 Number 1 June, 2017

Table 3: Mean mineral elements $(\mathrm{mg} / 100 \mathrm{~g})$ content in the different seasons at different weeks.

\begin{tabular}{|c|c|c|c|c|c|c|c|c|c|c|c|c|c|c|c|}
\hline 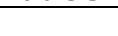 & $\mathrm{Mg}$ & 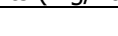 & & & 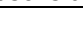 & $P$ & & & & & $\bar{K}$ & & & & \\
\hline Season & 6 weeks & 9 weeks & 12 weeks & Mean & LSD & 6 weeks & 9weeks & 12 weeks & Mean & LSD & 6weeks & 9weeks & 12weeks & Mean & LSD \\
\hline Rainy & 132.08 & 129.55 & 124.06 & 128.56 & 4.392 & 61.88 & 58.75 & 55.79 & 58.81 & 1.945 & 173.65 & 167.08 & 158.20 & 168.31 & 3.706 \\
\hline Dry & 121.77 & 117.47 & 107.24 & 115.49 & 2.346 & 63.13 & 58.53 & 53.93 & 58.53 & 2.091 & 170.43 & 162.27 & 155.01 & 162.57 & 3.353 \\
\hline Mean & 126.93 & 123.51 & 115.6 & & & 62.51 & 58.64 & 54.86 & & & 172.04 & 164.67 & 156.61 & & \\
\hline $\begin{array}{l}\text { LSD } \\
(0.05 \%)\end{array}$ & 3.640 & 3.083 & 2.591 & & & NS & NS & 1.769 & & & NS & 3.822 & 3.107 & & \\
\hline & $\mathrm{Ca}$ & & & & & $\mathrm{Na}$ & & & & & & & & & \\
\hline Season & 6 weeks & 9 weeks & 12 weeks & Mean & LSD & 6 weeks & 9weeks & 12 weeks & Mean & LSD & 6weeks & 9weeks & 12weeks & Mean & LSD \\
\hline Rainy & 197.90 & 202.07 & 217.40 & 205.79 & 5.51 & 78.51 & 77.13 & 76.56 & 77.40 & NS & 4.099 & 3.930 & 3.809 & 3.946 & NS \\
\hline Dry & 174.68 & 185.05 & 193.26 & 184.33 & 2.998 & 86.82 & 83.24 & 76.72 & 82.26 & 0.849 & 3.810 & 3.358 & 2.984 & 2.984 & 0.211 \\
\hline Mean & 186.29 & 193.56 & 205.33 & & & 82.67 & 80.18 & 76.6 & & & 3.954 & 3.358 & 3.396 & & \\
\hline $\begin{array}{l}\text { LSD } \\
(0.05 \%)\end{array}$ & 5.91 & 4.81 & 5.10 & & & 2.395 & 4.24 & NS & & & 0.129 & 0.286 & 0.278 & & \\
\hline & $\mathrm{Mn}$ & & & & & & & & & & & & & & \\
\hline Season & 6 weeks & 9 weeks & 12 weeks & Mean & LSD & & & & & & & & & & \\
\hline Rainy & 3.730 & 3.641 & 3.189 & 3.520 & 0.269 & & & & & & & & & & \\
\hline Dry & 3.651 & 3.306 & 2.924 & 3.294 & 0.192 & & & & & & & & & & \\
\hline Mean & 3.690 & 3.474 & 3.407 & & & & & & & & & & & & \\
\hline $\begin{array}{l}\text { LSD } \\
(0.05 \%)\end{array}$ & NS & 0.286 & 0.196 & & & & & & & & & & & & \\
\hline
\end{tabular}


Bajopas Volume 10 Number 1 June, 2017

Table 4: Mean lipid (\%) content in the different varieties, treatments and seasons at different weeks after sowing.

\begin{tabular}{|c|c|c|c|c|c|}
\hline Treatment & 6 weeks & 9 weeks & 12 weeks & Mean & $\begin{array}{l}\text { LSD } \\
(0.05 \%)\end{array}$ \\
\hline IT89KD - 288 & $0.412 a$ & $0.305 b$ & $0.267 b$ & 0.328 & 0.050 \\
\hline Kanannado & $0.397 \mathrm{~b}$ & $0.381 a$ & $0.307 a$ & 0.353 & 0.026 \\
\hline Mean & 0.397 & 0.354 & 0.287 & & \\
\hline LSD $(0.05 \%)$ & 0.015 & 0.035 & 0.004 & & \\
\hline Treatment & 6 weeks & 9weeks & 12weeks & Mean & $\operatorname{LSD}(0.05 \%)$ \\
\hline $150 \% \mathrm{~N}$ & $0.363 b$ & $0.337 c$ & $0.261 \mathrm{c}$ & 0.320 & 0.0148 \\
\hline 200ppm BAP & $0.433 c$ & $0.389 b$ & $0.299 b$ & 0.374 & 0.021 \\
\hline $150 \% \mathrm{~N}+200 \mathrm{ppmBAP}$ & $0.500 \mathrm{a}$ & $0.442 a$ & $0.331 a$ & 0.444 & 0.0154 \\
\hline Control & $0.290 d$ & $0.247 d$ & $0.197 d$ & 0.244 & 0.0152 \\
\hline Mean & 0.397 & 0.354 & 0.287 & & \\
\hline LSD $(0.05 \%)$ & 0.024 & 0.041 & 0.012 & & \\
\hline Season & 6 weeks & 9 weeks & 12weeks & Mean & LSD(0.05\%) \\
\hline Rainy & $0.408 a$ & $0.369 a$ & $0.290 a$ & 0.356 & 0.0200 \\
\hline Dry & $0.386 a$ & $0.338 a$ & $0.262 b$ & 0.328 & 0.0117 \\
\hline Mean & 0.397 & 0.354 & 0.276 & & \\
\hline LSD $(0.05 \%)$ & NS & NS & 0.026 & & \\
\hline
\end{tabular}

Table 5: Mean number of days to onset, progression and duration of senescence in the different varieties, treatments and seasons.

\begin{tabular}{|c|c|c|c|c|c|}
\hline Parameters & Onset of senescence & 50\%senescence & 90\%senescence & TDOP & DOS \\
\hline \multicolumn{6}{|l|}{ Variety } \\
\hline IT89KD288 & 64 & 81 & 93 & 102 & 38 \\
\hline Kanannado & 72 & 91 & 102 & 114 & 42 \\
\hline Mean & 68 & 86 & 98 & 110 & 40 \\
\hline $\operatorname{LSD}(0.05 \%)$ & 2.41 & 2.98 & 2.87 & 2.17 & 1.98 \\
\hline Treatments & Onset & $50 \%$ senescence & 90\%senescence & TDOP & DOS \\
\hline $150 \% \mathrm{~N}$ & 66 & 82 & 96 & 105 & 39 \\
\hline 200ppm BAP & 77 & 97 & 106 & 120 & 42 \\
\hline $150 \% N+200 p p m B A P$ & 72 & 96 & 110 & 121 & 48 \\
\hline Control & 57 & 69 & 81 & 92 & 35 \\
\hline Mean & 68 & 86 & 98 & 110 & 41 \\
\hline LSD $(0.05 \%)$ & 5.41 & 7.43 & 4.34 & 3.84 & 2.82 \\
\hline Season & Onset & $50 \%$ senescence & 90\%senescence & TDOP & DOS \\
\hline Rainy & 69 & 81 & 104 & 117 & 47 \\
\hline Dry & 67 & 91 & 91 & 102 & 35 \\
\hline Mean & 68 & 86 & 98 & 110 & 41 \\
\hline LSD $(0.05 \%)$ & 1.72 & 2.74 & 4.34 & 1.84 & 1.23 \\
\hline
\end{tabular}

TDOP- Total Death of Plant; DOS- Duration of senescence

\section{REFERENCES}

Ahenkora, K., AduDapaah, H.K., Agyemang, A. (1997). Selected Nutritional Components and Sensory Attributes of Cowpea (Vigna unguiculata [L.] Walp) leaves. Plant Foods in HumanNutrition, 52, 221-229.

Amujoyegbe, B.J., Opabode,J.T. and Olayinka, A. (2001). Effect of organic and Inorganic Fertilizer on Yield and Chlorophyll Content of Maize (Zea mays L.) and sorghum (Sorhum biocolour L.) (Moench). African Journal of Biotechnology, 6: 1869-1873.

Anes, M. and Johnson, W.S. (1980). A guide for the Hydriponic and Soillers .pp1-124. The Haworth Press, New York, USA.

Asante IK, Adu-Dapaah H and P Addison. (2006): Seed weight and protein and tannin contents of 32 cowpea accessions in Ghana. Journal of Tropical Science; 44(2):77-79.

Ben-Rais, L. Alpha, M.J. and Bhal, J. (1993). Lipid and protein contents of jojoba leaves in relation to salt adaptation. Plant Physiology,31:547-557.

Brown, J.H., Lynch, D.V. and Thompson, J.E. (1987). Molecular species specificity of phospholipids breakdown in microsomal membrane of senescing carnation flowers. Plant Physiology, 85:679-683.

Castillo,M.C. and Leon, J. (2008). Expression of the Betaoxidation Gene 3-ketoacyl-CoA Thiolase 2 (KAT2) is required for the Timely Onset of Natural and Dark-induced Leaf Senescence in Arabidopsis. Journal of Experinmental Botany, 59 2171-2179 
Droillard M.J., Bureau, D. and Paulin, A. (1989). Changes in Activities of Superoxide dismutase During Aging of Petals of Cut Carnations (Dianthus Caryophyllus). Physiology of Plant, 76:149155.

Duxbury, C.L., Legge, R.L., Paliyath, G., Barber, R.F. and Thompson, J.E. (1991). Alterations in membrane protein conformation in response to senescence - related changes. Phytochemistry, 30:6368.

Ejaz AW, Rashid A, Saifullah, Ashraf MY, Ehsanullah (2011). Role of Mineral Nutrition in Alleviation of Drought Stress in Plants. School of Earth and Environment, University of Western Australia, 35 Stirling Highway, Crawley, WA 6009 Australia. pp. 141-168.

Fery, R.L., Singh, B.B. (1997). Cowpea genetics: A review of the recent literature, in: Advances in cowpea research. Singh, B.B., Mohan, R.D., Dashiell, K.E. and Jackai, L.E.N. (Eds),. IITA, JIRCAS, Devon, Pp: 13-29.

Gomide, J.A. 1989. Mineral Composition of Grasses and Tropical Leguminous Forages.In: Latin American Symposium on Mineral Nutrition Research with Grazing Ruminants. University of Florida, Gainesville, Florida. pp. 32-40.

Green, P.B. and Jones, R.L. (1982). Light Quality Photoperception and Plant Strategy. Annual Review of Plant Physiology. Pp 20-28

Havlin JL, Tisdale SL, Nelson WL, Beaton JD (2007) Soil Fertility and Fertilizer, An Introduction to Nutrient Management 7th Edition Prentice Hall, Upper Saddle River, NJ, U.S.A.

Jones, D.I.H. (1983). The Mineral Content of Six Grasses from a Hyparrhenia-dominant grassland in Northern Rhodesia. Rhodesia. Journal of Agricultural Research, 1:33-38.

Lim, P.O., Woo, H.R. and Nam, H.G. (2007). Molecular Genetics of Leaf Senescence. Annual Review of Plant Biology, 58 115-136.

Maerere, A. P. and Ishimine,Y.( 2001). Effect of Organic Manure and Planting Pattern on Growth and Yield of Turmeric. African Journal of Science and Technology, 1: $14-21$.

Maposse, I.C. and Nhampalele, V.V. (2009).Performance of Cowpea Varieties under different Defoliation Regimes for Multiple uses. African Crop Science Conference, 9: 279-281.

Mazid, M.A. (1993). Exploring nitrogen remobilization for seed filling using natural variation in Arabidopsis thaliana. Ph.D dissertation. University of the Philippines at Los Banos.232 pp.

Mishra, S., Shanker, S. and Sangwan, R.S. (1998). Lipid profile in Relation to Tropane Alkaloid Production and Accumulation during Leaf Growth and Senescence in Duboisia myoporoides. Fitoterapia 69:65-72.

Myers, R.L.(1998). Nitrogen Fertilizer Effect on Grain Amaranthus. Agronomy Journal, 90: 597-602.

Nielsen, S.S., Ohler, T.A., Mitchell, C.A. (1997). Cowpea leaves for human consumption: production, utilization, and nutrient composition, in: Singh, B.B., Mohan, R.D., Dashiell, K.E., Jackai, L.E.N. (Eds), Advances in cowpea research. IITA, JIRCAS, Devon, pp: 326-332.

Nooden, L.D., (1979). Senescence and aging in plants. Sandiego, CA. Academic Press, Inc.Pp. 391 439.
Noubissié, T.J.B., Bell, J.M., Ngakeu, D.F., Njintang, Y.N., Youmbi, E. (2011b). Diallel analysis of cowpea (Vigna unguiculata L. Walp.) for some physical properties of seed under the Sudano-Guinean conditions.Agricultural and Biological Journal of America, 2(4), 698-707.

Olaleke AM, Olorunfemi O and TE AkintayoCompositional evaluation of cowpea (Vignaunguiculata) and scarlet runner bean (Phaseoluscoccineus) varieties grown in Nigeria. Intern. J. of Food, Agric. and Envir. 2006; 4 (2): 39-43.

Paliyath, G. and Droillard, M.J. (1992).The mechanisms of membrane deterioration and disassembly during senescence. Plant Physiology of Biochemestry, 30:789-812.

Palta JP (2000). Supplemental Calcium Application influences Potato Tuber number and size. Department of Horticulture, 1575 Linden drive, University of Wisconsin Madison. Plant Journal.14: 99-111

Ricardo, B., Jorge, M.G., Luiz, G.E. and Mario, M. (1987). Effect of fertilizer application on the yield, protein, and lipid content of three amaranth species. Plant foods for human nutrition, 37: 59-67.

Richmond, T.A. and Lang, B.A (1994). The fate of infloresnece meristem is controlled by developing fruits in Arabidopsis. Plant physiology, $106: 863-876$.

Sebetha, E.T., Ayodele, V.I., Kutu, F.R., Mariga, I.K. (2010). Yields and protein content of two cowpea varieties grown under different practices in Limpopo province, South Africa. African Journal of Biotechnology, 9(5), 625-634.

Seobi, T. (2005).Effect of farmyard manure on growth and yield of turmeric. Soil Science American Journal,69: 893 - 901.

Singh, B.B., Mohan, R.D., Dashiell, K.E. and Jackai, L.E.N. (2003). (Eds), Advances in cowpea research. IITA, JIRCAS, Devon, Pp: 326-332.

Smith, W. and Watson, B. (1988).Nutritional value of crops as influenced by organic and inorganic fertilizer treatments. Results of 12 years' experiments with vegetables (1960-1972) Qual. Plant. Plant Foods and Human Nutrition. 23(4): 333-358.

Springer, T.L., Taliaferro, C.M. and Hattey,J.A.(2005). Nitrogen source and rate effect on the production of buffalo grass forage grown with irrigation. Crop Science, 45: 668-672.

Usoro, C.A.O., Adikwuru, C.C., Usoro, I. N. and Nsonwu, A.C. (1982).Lipid profile determination using soxhlet extraction method. Plant Physiology and Biochemistry,33: 547-553.

Vanek, V. (2003).Farm yard manure application on root crops for higher yield. Plant Soil and Environmental journal 49:197 - 202

Whalen, J. K. (2000). The usage of chemical fertilizer, improving economy in agriculture and minimizing environmental problems. Science American Journal. 64: 962 - 966.

World Weather information service Lagos (2012).World Meteorological Organization.

Xio O,and Li, K.( 2006). Turmeric as a medicinal plant. Plant Production Science 6: $3-89$ 